\title{
A framework for the management of sand dune systems in Wales
}

\author{
Peter Rhind • Rod Jones
}

Received: 18 March 2008 /Revised: 10 December 2008 /Accepted: 23 February 2009/Published online: 26 March 2009

(C) The Author(s) 2009. This article is published with open access at Springerlink.com

\begin{abstract}
The Countryside Council for Wales (CCW) is developing a management framework with the primary aim of restoring favourable conservation status to the sand dune resource of Wales. It will take onboard the requirements of both national and international conservation legislation and will also help CCW integrate its responsibilities for biodiversity, geodiversity, landscape, access and recreation for this habitat. In order to achieve certain conservation goals it will be necessary to have in place a variety of different types of management ranging from non- or minimal intervention through to intensive single species management and habitat re-creation. However, it will not provide a comprehensive framework for all aspects of site management, but only those that are deemed to be of strategic importance, and have significance within an all-Wales perspective for their nature conservation importance.
\end{abstract}

Keywords Favourable conservation status · Dune systems

\section{Introduction}

As the Government's statutory adviser on sustaining natural beauty and wildlife in Wales, the Countryside Council for Wales (CCW) has been developing a management frame-

P. Rhind $(\bowtie) \cdot$ R. Jones

Countryside Council for Wales,

Maes-y-Ffynnon, Penrhosgarnedd,

Bangor, Gwynedd LL57 2DN Wales, UK

e-mail: p.rhind@ccw.gov.uk

R. Jones

e-mail: rod.jones@ccw.gov.uk work to help promote the long-term conservation of dune systems in Wales. The main drivers are the EC Council Directive 92/43/EEC on the conservation of natural habitats and wild fauna and flora (EC Habitat and Species Directive), the UK's Wildlife and Countryside Act and the Convention on Biological Diversity (UK Government 1994). In addition the framework will help:

- Integrate CCW's key responsibilities for landscape, geomorphology, habitats, species, access and recreation

- Underpin dialogue with key partners

- Justify short term potentially 'damaging' management for the long term good of the resource. This is likely to be very important in relation to the Habitats Directive (enshrined in UK law in the Habitat Regulations)

- Justify deployment of resources

- Ensure that dune Special Areas Of Conservation (SACs) are in favourable condition or that any remedial mechanisms are in place

- Site managers manage their sites within a co-ordinated all-Wales perspective

A further aspect of the rationa'le is to manage the dune resourse of Wales in a more holistic fashion with the aim of optimising its resilience to various negative environmental factors and to help maximise its conservation value. This level of control enables us to set clear management priorities that for any one site could possibly be seen as negative, but when viewed as part of the overall scheme can be more cogently justified, particularly to the wider public. CCW has in the past lacked the capacity to address these issues at an all-Wales level, but in general we aim to allow natural processes to operate or to create the conditions condusive to their operation. 
Key responsibilities of the Countryside Council for Wales

CCW's role encompasses landscape, access and recreation as well as geodiversity and biodiversity. Reconciling these interests is often been done at site level without any consideration of the resource as whole. The framework will aim to address these issues in a more strategic and systematic way, but in this summary account only elements affecting landscape, biodiversity and geodiversity will be detailed.

\section{Biodiversity}

Altogether, there are about 6,500 ha of unforested dune habitat remaining in Wales (Fig. 1). Nevertheless, within this comparatively small area, these dunes support 67 species that are either restricted to or strongly associated with dune habitat, 51 Red Data Book species, 9 species protected under Schedule 8 of the UK's Wildlife and Countryside Act, and six species protected under either Annex II or Annex V of EC Habitat and Species Directive (Rhind and Jones 1999). It is not surprising therefore that much of the remaining resource has been given some form of legal protection (Fig. 2, Table 1). In terms of species conservation, sand dunes are mainly important for flowering plants, bryophytes, fungi, lichens and invertebrates. In the past there has been the misconception that diversity in one group of organisms acts as a surrogate for diversity in other groups, and that if management is right for one group others will benefit. This is now known to be incorrect (Prendergast et al. 1993) and, in fact, 'hot spots' for one group of organisms rarely overlap with 'hot spots' for other groups. We have therefore distinguished which sand dune sites are important for each of the above-mentioned groups and, as expected, several sites are recognised as important for two, three or even all of these groups. This may appear to contradict Prendergast's claims but there are still clear conflicts between the management requirements of different taxonomic groups. For example, rank grassland may be important for certain invertebrates, but is of no value whatsoever for plant diversity.

\section{Geodiversity}

Sand dune represent an important geomorphological resource and a number of Welsh dunes have been identified as important for their coastal geomorphology by the UK Geological Conservation Review (May and Hanson 2003). Sand dunes form all or parts of seven different Geological Conservation Review (GCR) sites in Wales. These are active process sites and a key element of their management is to sustain this interest to ensure that active geomorphological processes continue.

\section{Landscape}

Sand dunes are a vital part of the coastal landscape of Wales. Five systems are within designated Areas of Outstanding Natural Beauty (AONB); seven lie within Heritage Coast (HC) and seven are in National Parks (NP). Maintaining the quality of these landscape as far as sand dunes are concerned is intimately linked to maintaining their natural processes as far possible. It is generally agreed that when systems are in a dynamic state reflected in levels of open sand and vegetation characteristic of mobile and semi-mobile dunes that these add to the character and diversity of the landscape.

\section{Welsh Sand Dune Resource}

relative proportions of the major sand dune vegetation categories found in Wales based on data collected in the 1980 s and 1990 s

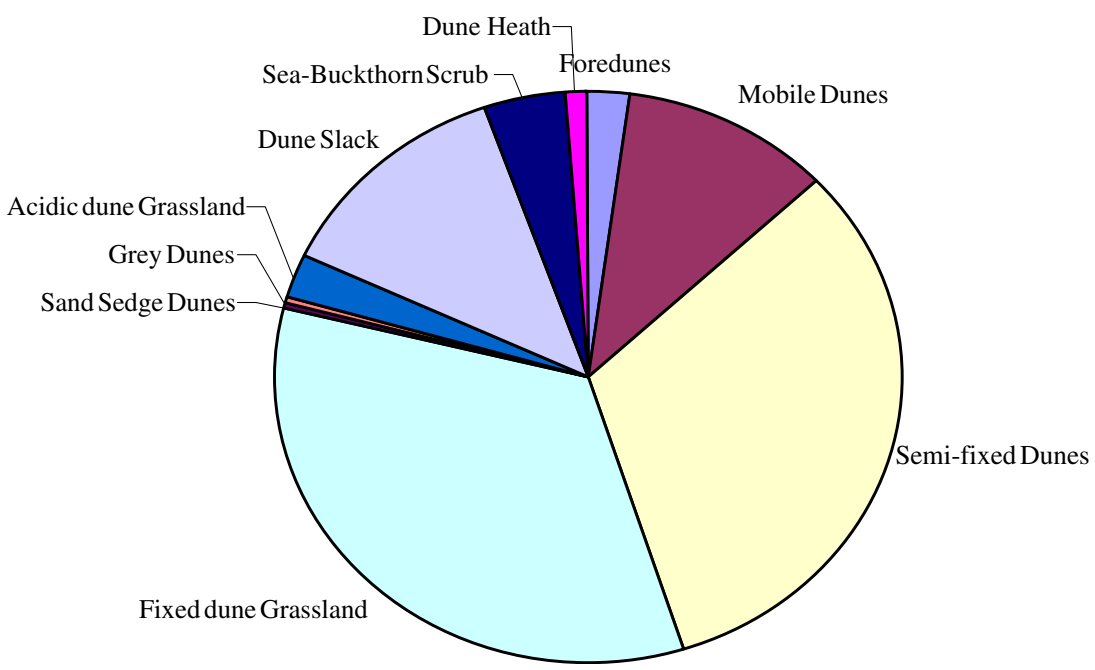


Fig. 2 Locations and conservation status of sand dune sites in Wales. Site names are given in Table 1. This OS base map has been reproduced with permission of HMSO. Crown copyright reserved. CCW licence No. 100018813 (Scale 1: 1253585.5)

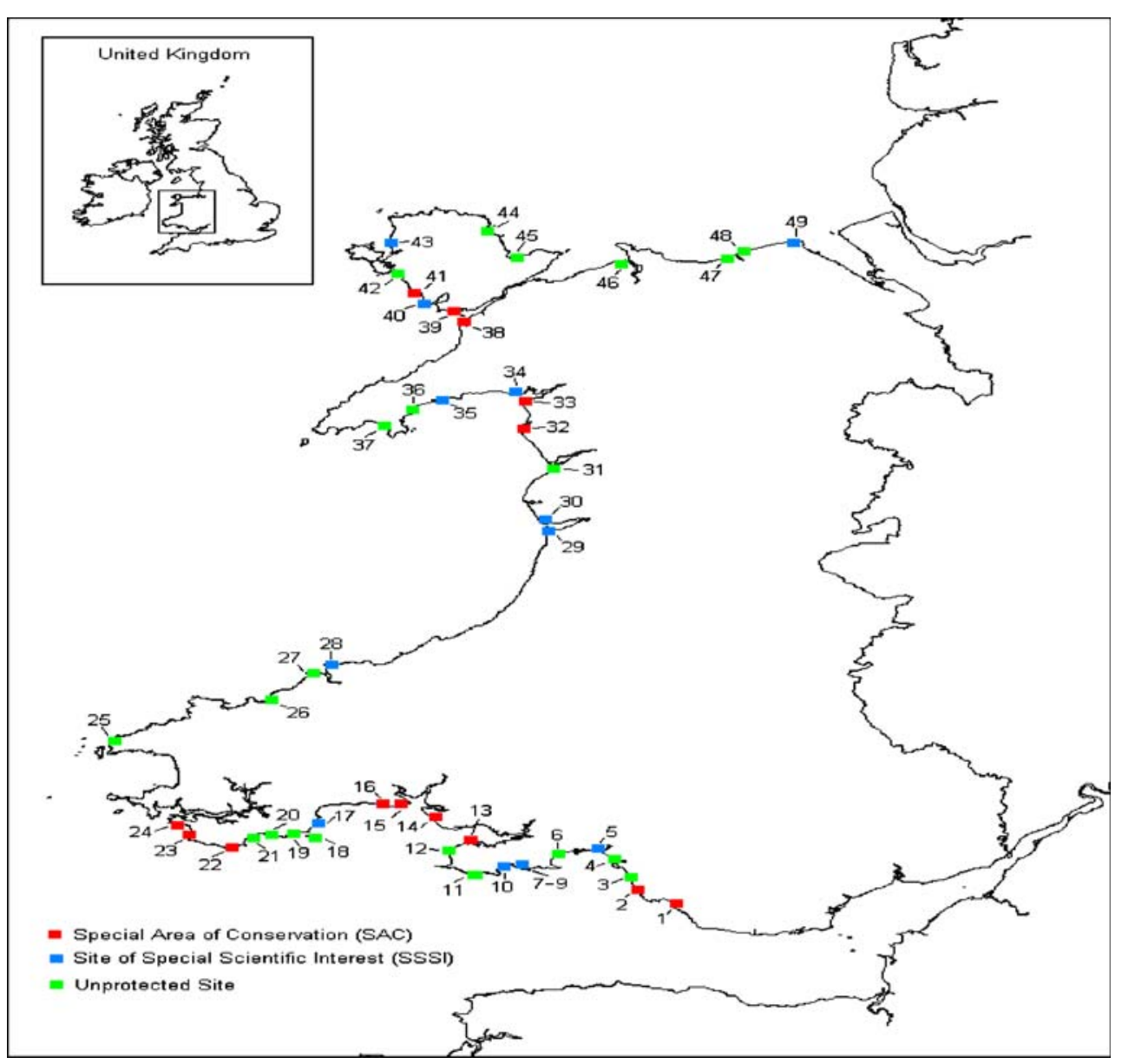

\section{Management framework}

In order to achieve certain key conservation goals it has been deemed necessary to have in place a variety of different types of management ranging from total non- or minimal intervention through to intensive single species management and habitat re-creation. Dune sites across Wales have now been selected for one or more forms of intervention management. However, as sand dunes are natural habitats, intensive intervention is only being used when absolutely necessary. The main types of management required can be summarised as follows:

- Maintaining or restoring sand supply

- Encouraging localised destabilisation

- Reducing the impact of nutrient enrichment

- Optimising water supply

- Creation of Atlantic dune woodland

- Removal on non-native trees (mainly conifers)

- Implementing the re-creation or re-invigoration of dune slack

- Implementing scrub control

- Establishing appropriate grazing levels

- Combating the impact of climate change and sea level rise
Maintaining or restoring sand supply

At least 27 of the 49 dunes systems in Wales are now subject to net erosion (Dargie 1995). This is a major concern and possibly constitutes an intractable problem for certain sites. Beach nourishment is one solution but this is an extremely expensive operation, but its value has been clearly demonstrated at Talacre Warren in North Wales. Here in $2003,150,000 \mathrm{~m}^{3}$ of dredged sand was pumped on to the foreshore along a section of eroding dunes. Material of a suitable quality was made available from navigation dredging operations in the Dee Estuary thereby significantly reducing the cost. New foredunes are now developing and sand is now being channelled into hind dune areas creating new mobile dunes. The process has re-invigorated the dunes as whole by causing a much-needed increase in the overall level of sand mobility (Fig. 3). Further opportunities for using dredge material are being sought.

Encouraging localised destabilisation

Recent studies (e.g. Rhind et al. 2001) show that the level of sand mobility on Welsh dunes system has radically 
Table 1 Dune systems in Wales and their designations in terms of conservation status. Abbreviations are as follows: $\mathrm{SSSI}=$ Site of Special Scientific Interest, $N N R=$ National Nature Reserve, $S A C=$ Special Area of
Conservation, $\mathrm{LNR}=$ Local Nature Reserve, $\mathrm{AONB}=\mathrm{Area}$ of Outstanding Natural Beauty, HER $=$ Heritage Coast, $\mathrm{NP}=$ National Park, $\mathrm{BIO}=\mathrm{Bio}-$ sphere Reserve, RAM=Ramsar Site, $\mathrm{GCR}=$ Geological Review Sites

\begin{tabular}{|c|c|c|c|c|c|c|c|c|c|c|c|c|c|}
\hline Site No. & Site & Area (ha) & Region & SSSI & NNR & SAC & LNR & AONB & HER & NP & $\mathrm{BIO}$ & RAM & GCR \\
\hline 1 & Merthyr Mawr & 342 & Bridgend & $\mathrm{x}$ & $\mathrm{x}$ & $\mathrm{x}$ & & & $\mathrm{x}$ & & & & \\
\hline 2 & Kenfig Burrows & 602 & & $\mathrm{x}$ & $\mathrm{x}$ & $\mathrm{x}$ & & & & & & & \\
\hline 3 & Margam Burrows & 101 & & & & & & & & & & & \\
\hline 4 & Baglan Bay & 78 & & & & & & & & & & & \\
\hline 5 & Crymlyn Burrows & 118 & Swansea & $\mathrm{x}$ & & & & & & & & & \\
\hline 6 & Black Pill to Bryn Mill & 16 & & & & & & & & & & & \\
\hline $7-9$ & Pennard, Penmaen \& Nicholaston & 87 & & $\mathrm{x}$ & & & & $\mathrm{x}$ & $\mathrm{x}$ & & & & \\
\hline 10 & Oxwich Burrows & 93 & & $\mathrm{x}$ & $\mathrm{x}$ & & & $\mathrm{x}$ & $\mathrm{x}$ & & & & $\mathrm{x}$ \\
\hline 11 & Port Eynon to Horton & 19 & & & & & & & & & & & \\
\hline 12 & Hillend to Hills Tor Burrows & 224 & & & & & & & & & & & \\
\hline 13 & Whiteford Burrows & 142 & & $\mathrm{x}$ & $\mathrm{x}$ & $\mathrm{x}$ & & $\mathrm{x}$ & $\mathrm{x}$ & & & & $\mathrm{x}$ \\
\hline 14 & Pembrey Burrows & 591 & Carmarthenshire & $\mathrm{x}$ & & & & & & & & & $\mathrm{x}$ \\
\hline 15 & Laugharne Burrows & 431 & & $\mathrm{x}$ & & $\mathrm{x}$ & & & & & & & $\mathrm{x}$ \\
\hline 16 & Pendine Burrows & 173 & & $\mathrm{x}$ & & $\mathrm{x}$ & & & & & & & $\mathrm{x}$ \\
\hline 17 & Tenby Burrows & 92 & Pembrokeshire & $\mathrm{x}$ & & & & & $\mathrm{x}$ & $\mathrm{x}$ & & & \\
\hline 18 & Caldey Island & 3 & & & & & & & & & & & \\
\hline 19 & Lydstep Haven & 23 & & & & & & & & & & & \\
\hline 20 & Manorbier and Swanlake Bay & 10 & & & & & & & & & & & \\
\hline 21 & Freshwater Bay East & 17 & & & & & & & & & & & \\
\hline 22 & Stackpole Warren & 179 & & $\mathrm{x}$ & $\mathrm{x}$ & $\mathrm{x}$ & & & $\mathrm{x}$ & $\mathrm{x}$ & & & \\
\hline 23 & Brownslade \& Linney Burrows & 253 & & $\mathrm{x}$ & & $\mathrm{x}$ & & & & & & & \\
\hline 24 & Broomhill Burrows & 183 & & $\mathrm{x}$ & & $\mathrm{x}$ & & & $\mathrm{x}$ & $\mathrm{x}$ & & & \\
\hline 25 & Whitesand Bay & 28 & & & & & & & & & & & \\
\hline 26 & The Bennett & 20 & & & & & & & & & & & \\
\hline 27 & Poppit Sands & 11 & & & & & & & & & & & \\
\hline 28 & Towyn Warren & 30 & Ceredigion & $\mathrm{x}$ & & & & & & $\mathrm{x}$ & & & \\
\hline 29 & Ynylas & 68 & & $\mathrm{x}$ & $\mathrm{x}$ & & & & & & $\mathrm{x}$ & $\mathrm{x}$ & $\mathrm{x}$ \\
\hline 30 & Tywyn to Aberdovey & 111 & Gwynedd & $\mathrm{x}$ & & & & & & $\mathrm{x}$ & & & \\
\hline 31 & Fairbourne & 15 & & & & & & & & & & & \\
\hline 32 & Morfa Dyffryn & 313 & & $\mathrm{x}$ & $\mathrm{x}$ & $\mathrm{x}$ & & & & $\mathrm{x}$ & & & $\mathrm{x}$ \\
\hline 33 & Morfa Harlech & 341 & & $\mathrm{x}$ & $\mathrm{x}$ & $\mathrm{x}$ & & & & $\mathrm{x}$ & & & $\mathrm{x}$ \\
\hline 34 & Morfa Bychan & 169 & & $\mathrm{x}$ & & & $\mathrm{x}$ & & & & & & \\
\hline 35 & Pwllheli to Pen y Chain & 44 & & $\mathrm{x}$ & & & & & & & & & \\
\hline 36 & Traeth Crugan & 22 & & & & & & & & & & & \\
\hline 37 & Tai Morfa & 20 & & & & & & & & & & & \\
\hline 38 & Morfa Dinlle & 66.6 & & $\mathrm{x}$ & & $\mathrm{x}$ & & & & & & & $\mathrm{x}$ \\
\hline 39 & Newborough Warren & 529 & & $\mathrm{x}$ & $\mathrm{x}$ & $\mathrm{x}$ & & $\mathrm{x}$ & & & & & $\mathrm{x}$ \\
\hline 40 & Penhrhnoedd - Llangadwaladr & 25 & & $\mathrm{x}$ & & & & & & & & & \\
\hline 41 & Aberffraw & 248 & & $\mathrm{x}$ & & $\mathrm{x}$ & & $\mathrm{x}$ & & & & & $\mathrm{x}$ \\
\hline 42 & Valley Airfield & 192 & & & & & & & & & & & \\
\hline 43 & Tywyn Gwyn & 17 & & $\mathrm{x}$ & & & & & & & & & \\
\hline 44 & Traeth Dulas \& Traeth Lligwy & 7 & & & & & & & & & & & \\
\hline 45 & Red Wharf Bay & 6 & & & & & & & & & & & \\
\hline 46 & Conwy \& Deganwy Dunes & 75 & & & & & & & & & & & \\
\hline 47 & Kinmel Bay & 11 & & & & & & & & & & & \\
\hline 48 & Rhyl to Prestatyn & 53 & & & & & & & & & & & \\
\hline 49 & Gronant to Talacre & 190 & Flintshire & $\mathrm{x}$ & & $\mathrm{x}$ & & & & & & & \\
\hline
\end{tabular}


Fig. 3 Foredunes at Talacre Warren before and approximately 2 years after beach nourishment
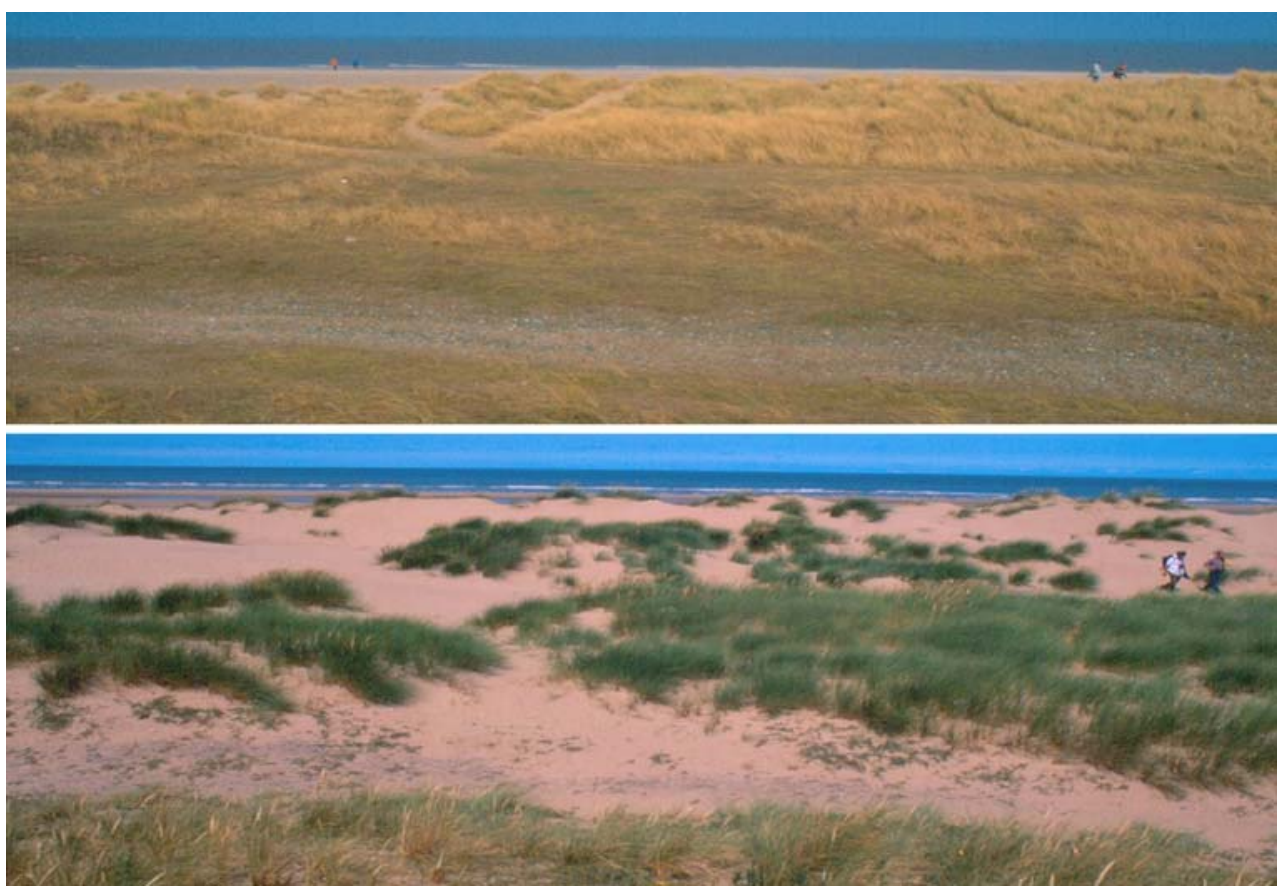

altered over the past five decades. For example, Newborough Warren was a much more mobile system in the 1950s (Fig. 4) with mobile dunes occupying over $70 \%$ of the site as opposed to just $6 \%$ today, and over half of the dune slacks at that time were in an embryonic state, a condition that is virtually none existent today. There is good evidence that this situation was typical for many other dune systems during that period and we can assume that Newborough was representative of the Welsh dune resource as a whole at that time.

The ratio of the area of 'mobile' to 'stable' habitat types can be taken to be an index of dune system mobility (Saye 2003). Only a few Welsh dune systems today have a mobility index greater than 1, notably Baglan Bay, Laugharne Burrows, Ynyslas, Morfa Dyffryn and Red Wharf Bay. The mobility index for Newborough Warren in the 1950s would have exceeded 8-today it is less than 0.4 . Sites provisionally selected for de-stabilisation programmes include Kenfig, Pembrey and Newborough Warren. All of these sites now have an extremely low mobility index. It seems likely that much of this destabilization will be generated through the reactivation of stabilized blowouts. Studies show (van Boxel et al. 1997) that for these to remain active the area of destabilization needs to be in excess of $50 \mathrm{~m}^{2}$. Reactivations of blowouts smaller than this tend to rapidly re-stabilize. It was also found essential to remove all soil material exposing original bare sand. However, this study was based on artificially stabilised blowouts, whereas in Wales we are largely dealing with blowouts that have stabilized in the absence of any obvious human activity. There is also now some evidence (Arens and Geelen 2006) that even extensively destabilized areas (tens of hectares) are likely to re-stabilize within a few decades and that new measure to reduce stabilization may be required every 10 or 20 years.

\section{Reducing the impact of nutrient enrichment}

The stabilization of dunes is thought to be at least in part attributable to the input of artificially high levels of

Fig. 4 A photograph of Newborough Warren taken by Derek Ranwell in the 1950s. This type of vegetation, described as a mobile Salix community, no longer occurs in the UK

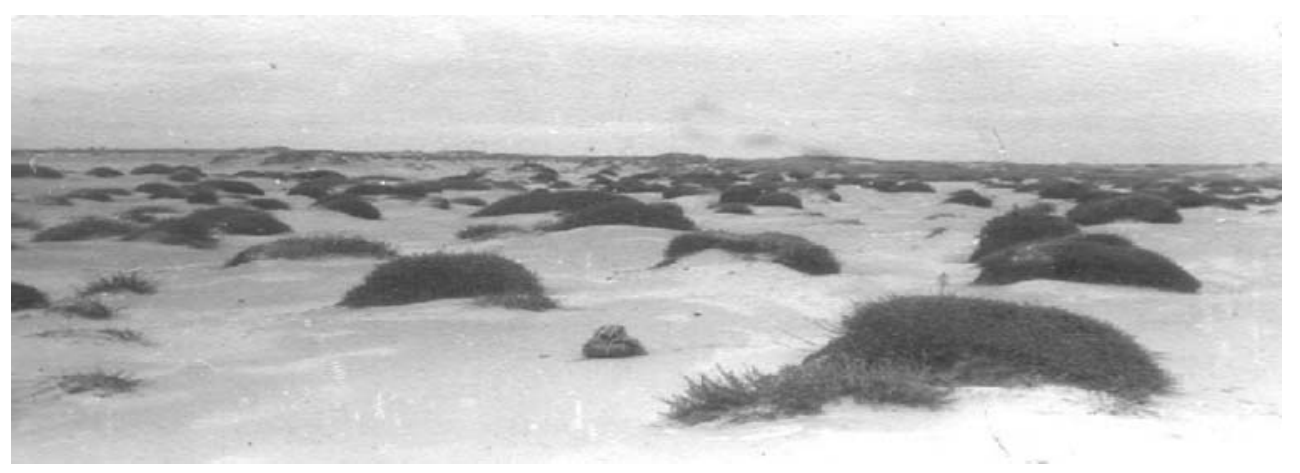


nitrogen from atmospheric and ground water sources. The recommended critical load range for sand dunes is 10 $20 \mathrm{~kg} \mathrm{~N} \mathrm{ha}^{-1} \mathrm{yr}^{-1}$ (Jones et al. 2002a, b, 2004, 2005) and several sites in Wales are now regarded as approaching threshold levels on the basis of atmospheric inputs alone. To reduce further inputs we are proposing the establishment of buffer zones around certain sites and looking into the possibility of designating certain water catchments as Nitrogen Sensitive Areas. CCW is also supporting strategic efforts to reduce background NOx and ammonia levels. We initiated the research that led to the establishment of the above critical load figure and are now supporting strategic efforts to understand the impacts of high background levels of NOx and ammonia and how best to implement their reductions. This is being carried out via two main approaches. The first aims to influence policy to reduce air pollution in order to protect vulnerable habitats such as sand dunes. This is delivered through our advice to Department for Environment, Food and Rural Affairs (Defra) on revisions to the UK Air Quality Strategy. The second is by supporting research to gain an evidence based approach to the establishment of appropriate pollution thresholds. A recent example of this was through research funded by $\mathrm{CCW}$ in collaboration with the Joint Nature Conservation Committee (JNCC) to lower the UNECE critical level for ammonia from $8 \mu \mathrm{g} / \mathrm{m}^{3}$ to $1 \mu \mathrm{g} / \mathrm{m}^{3}$ for lichens and to $3 \mu \mathrm{g} / \mathrm{m}^{3}$ for other plants (Cape et al. 2009).

\section{Optimising water supply}

The water tables of various dune systems have been significantly lowered as a result of local drainage schemes. Although there is little hard evidence to show how dune slack vegetation has been affected by this, there is now a high degree of certainty that it has had a detrimental effect on certain sites (see for example Environment Agency Wales (EAW) 2006). There is now, however, the possibility of resolving this issue at certain sites through the implementation Water Level Management Plans. These are prepared by the UK's Environment Agency (EA) and aim to reconcile and integrate the water level requirements for a range of activities, including agriculture, flood defence and conservation, but with priority given to maintaining or restoring hydrological regimes that are important to conservation features of national or international importance. CCW is now working in close partnership with EA to help restore more natural hydrological regimes to various dune sites.

\section{Creation of Atlantic dune woodland}

Atlantic dune woodland is defined as any natural or seminatural forests (long established) of Atlantic coastal dunes with a well-developed woodland structure supporting an assemblage of characteristic woodland species. It corresponds to oak and beech-oak groves with birch (Quercion robori-petraeae) on acid soils, as well as forests of the Quercetalia pubescenti-petraeae order. Pioneer stages are open forests with Betula spp. and Crataegus monogyna, mixed forests with Fraxinus excelsior, Quercus robur, Ulmus minor and Acer pseudoplatanus or, in wet dune slacks, pioneer forests with Salix alba with the potential to develop into humid mixed forests or marsh forests.

One of the biodiversity action plan requirements for dunes systems in the UK is to actively encourage the development of Atlantic dune woodland on up to five carefully selected sites. A number of sites in Wales have been provisionally earmarked for this. Three of these (Newborough, Morfa Harlach and Pembrey) have existing conifer plantations, and there is potential for converting these into much more natural forests by promoting the development of native species and removing, where necessary, non-native species.

\section{Removal on non-native trees (mainly conifers)}

Conifer plantation now occupies some 1,700 ha (approximately $21 \%$ ) of dune habitat in Wales and has a major impact on the conservation status of the resource. Apart from the loss of habitat they also have a major stabilizing influence by suppressing natural geomorphological processes and can adversely affect the hydrology of adjacent dunes. Sites that include conifer plantations are Newborough Warren, Pembrey, Whiteford Burrow and Morfa Harlech. All of these are designated SACs under the protection of the EC Habitats Directive, and it could be argued that these plantations are now in direct conflict with Directive requirements in terms of maintaining and enhancing favourable conservation status. In other words, their continued presence at some locations could be causing adverse impacts that could be interpreted as contravening European Law. We are, therefore, advocating their removal or partial removal but this has proved to be a contentious issue. Some of these plantations are highly valued by both local people and visitors and constitute a perceived asset to the local tourist industry.

Implementing the re-creation or re-invigoration of dune slack

Welsh dunes are extremely important for their dune slack components with over $57 \%$ of the entire British resource of the Sagina nodosa-Bryum pseudotriquetrum dune-slack community and a staggering $77 \%$ of the British Salix repens-Campylium stellatum dune-slack community. This is despite the fact that the remaining area of this habitat in 
Wales is just 615 ha out of a UK total of about 2,285 ha. Most of the rare species of dune systems occur in this habitat. It is crucial therefore that the remaining dune slack habitat is maintained in favourable condition, and that opportunities are sought to re-create additional habitat. Dune sites provisionally selected for dune slack re-creation or re-invigoration are Brownslade Burrows, Laugharne/ Pendine Burrows, Kenfig Burrows, Ynyslas, Pembrey Coast, Gronont and Talacre Warren and Newborough Warren.

Kenfig Burrows now represents a key site in Wales for dune slack rejuvenation. Work was initiated in the early 1990s by a process of mowing and scarifying and this work is now covering about 2 ha of dune slack per year on a rotational basis. Restoration of dune slack has also started at Talacre Warren. Here in 2004 scrub, with the exception of low growing creeping willow (Salix repens), willow trees were removed from an area of dune slack measuring approximately 1.3 ha (Fig. 5). Nutrient rich topsoil was also removed. Scrub and tree clearance from dune slacks has also been implemented at Ynyslas dunes.

\section{Implementing scrub control}

Natural or semi-natural scrub communities on dunes often including blackthorn and privet. These represent an important phase in the natural succession and can be important for certain bird species. However, there is now major concern regarding the invasive spread of seabuckthorn (Hippophae rhamnoides). This species is not native to Wales but has now become well established on a number of dune systems, and is particularly problematic at Merthyr Mawr. Over 52 ha have now been cleared at substantial cost. Much of it was grubbing out using an excavator fitted with a weed rake, while herbicide foliar spraying was used on smaller specimens. Several other sites have now been identified as requiring intensive scrub control. Hippophae rhamnoides is the only native species of the family Elaeagnaceae found in Britain and was probably widespread in late glacial times but then became restricted to a few coastal areas as post-glacial forests developed (Ranwell (ed) 1972). Studies by Groves (1958) based on the records of introductions for many site, suggest that today it can only be considered native to the coastal fringes of the south-east and eastern counties from Northumberland to East Sussex (see also Pearson and Rogers 1962). It was originally planted to stablize dunes at several sites in Wales spanning north, mid and south Wales, but was then probably spread by birds to other sites.

\section{Establishing appropriate grazing levels}

It is difficult to envisage what dune ecosystems were like prior to the arrival of man, but it is likely that they have always been grazed to a certain extent-firstly, by wild herbivores, and then later by domesticated stock. Grazing pressure was radically increased with the introduction of rabbits in the 11th century, especially where there populations were maintained artificially high on rabbit warrens, which include a number of dune systems in Wales. Today we are largely restricted to the use of domestic grazing stock which we use to either emulate natural grazing regimes or to maintain long-term traditional regimes. Choice of stock can influence a whole range of factors, both those affecting the conservation of the site, such as vegetation structure, plant composition, impact on rare species, and tree or scrub cover, but also on the practicalities of keeping stock, such as method of enclosure, staff or grazier involvement to manage the animals and so on (Boorman 1993). The main types of stock used on Welsh dunes are cattle, sheep and equines and each creates a characteristic range of dune habitat types (Tolhurst and

Fig. 5 Talacre dune slack before and after scrub control

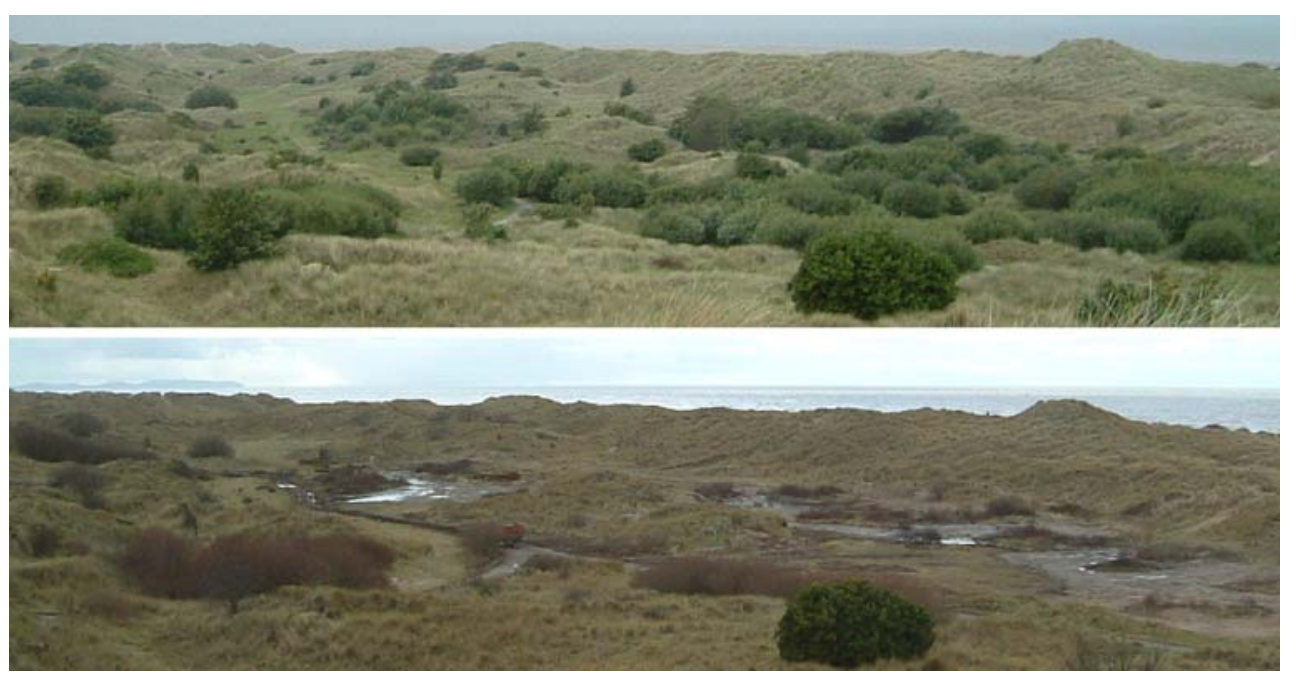


Oates 2001). To maintain the overall diversity of the sand dune resource in Wales, it is important therefore that we retain and possibly enhance the overall variety of grazing stock. Currently, 20 dune sites support grazing stock, but many of the current regimes are far from satisfactory. Prior to the outbreak of myxomatosis, dunes in Wales were often swarming with rabbits and their grazing and scratching had a profound influence on the vegetation. The resulting reduction in grazing pressure gave rise to conditions much more suitable for scrub invasion and the proliferation of coarse grasses (Ranwell 1960, Hodgkin 1984). However, whether the present stabilisation event could have been offset by a flourishing rabbit population is still open to debate since it seems to have proceeded prior to the advent of myxomatosis at Newborough Warren, for example (Rhind et al. 2001). Nevetheless, rabbits have been an important component of Welsh sand dunes for at least the last 900 years but today the distinctive lichen and moss rich dune grassland they create is restricted to just a handfull of sites such as Aberffraw and Morfa Dinlle. For this reason, we have provisionally selected a number of sites that will be encouraged to develop in to modern day 'rabbit warrens', and as part of this strategy, a programme of rabbit re-introductions is being considered. However, under present conditions it is unlikely that rabbit grazing alone could maintain open grasslands.

Combating the impact of climate change and sea level rise

Sea level rise is an important issue in sand dune management not least because of their flood defence role. Pye and Saye (2005), using an assumed sea level rise of $0.41 \mathrm{~m}$ by 2,100 (the median value based on IPCC predictions), have predicted that several sites in Wales are likely to experience significant net loss of dune area/habitat over the course of the next century, notably Morfa Dyffryn, Newborough Warren, Whiteford Burrows and Kenfig. However, these values may underestimate likely changes due to recently revised estimates for sea level rise. According to the Defra (2006) a sea level rise of the order of about $1.1 \mathrm{~m}$ is predicted by 2,100. Rollback is one possible solution (i.e. allowing dunes to migrate landward. However, most dune systems in Wales are highly stabilised by vegetation and unable to migrate. Even where dune migration might be possible, it is often constrained by coastal assets such as golf courses. The predicted annual rise in average temperature by 1 to $3^{\circ} \mathrm{C}$ or more during the coming century is also of concern. However, many dune species in Wales, particularly plants and invertebrates have a southern distribution and tend to be thermophilic, and therefore likely to cope with such changes. There are exceptions, such as the dune grass Leymus arenarius, which is close to its southern limit in Wales.

\section{Conclusions}

CCW has found the process of creating a strategic management framework a valuable exercise in its own right. It has forced the organisation to analyse in a more rigorous way the key conservation elements of the resource. It has also:

- Resulted in a much clearer documentation of the resource and key features

- A clearer understanding of the management issues

- An improved sharing of problems and issues within the organisation

However, it should be stressed that this is not something that $\mathrm{CCW}$ can do in isolation and will require collaboration with other organisations and landowners. The strategic delivery of CCW's habitat management requirements is constrained by a number of external factors. Most notably is their flood defence role preventing inundation of lowlying land. Management to increase the mobility of such dunes is likely to come into conflict with this function.

Surprisingly, even some of the legislation, particularly the EC Habitats Directive, has imposed a number of unwelcome constraints in our view. Grey dune, for example, has been given Priority Habitat status meaning that the EC has a particular responsibility for its conservation since most of the global resource occurs within EC member states. According to Article 6, where a site hosts a Priority Habitat type the only considerations with regards to its potential loss are those relating to human health or public safety, to beneficial consequences of primary importance for the environment or, further to an opinion from the Commission, to other imperative reasons of overriding public interest. In other words, attempts to allow processes, such as natural succession or geomorphologic development that may impinge upon grey dunes could be in breach of European law. This, in our view, is too draconian and goes against the concept of ecosystem management. In most cases we will be encouraging the development and improvement of grey dunes, but there are occasions where, in our view, for the good of the resource as whole, it would have been better to allow its partial loss to either natural succession or through expanded destabilization.

There now seems little doubt that dune systems in Wales and probably throughout Europe are facing unprecedented threats to their long-term conservation. Lack of sand supply, reduced mobility, nutrient enrichment, soil development and climate change are all conspiring to severely degrade their conservation value. All of these factors can be linked in varying degrees to anthropogenic induced changes, but sand dunes may also be facing threats from natural geomorphological factors. In geological time, dunes are transient features and probably only fully functional 
either under a continuing supply of sand or where there is sufficient mobility to allow sand to be recycled back and forth between sand flats and sand dunes. Our studies show that this is certainly not the case for many of the remaining dune systems in Wales, and it could be argued that these are now relict dunes rather than fully functioning dune ecosystems. In fact, the absence of primary accretion has been ascribed to the ending of a long phase of excessive quantities of sand sized sediment in shallow coastal waters created during the glacial period and the evidence suggests that dune geomorphology is now entering a phase of senility (Ritchie 2001). This geomophological maturity, however, is not reflected in the maturity of the vegetation. Grazing and other influences have held most coastal dunes systems to a sub-climax or plagioclimax with varying amounts of shrub and tree cover. In all likelihood, in the absence of this interference, large parts of our dune systems would be well on their way towards developing into mature woodland by now.

These pressures suggest that there is likely to be an increasing requirement for management intervention and given the fact that resources will always be limited, a clear management framework will be fundamental to driving this process forward.

Open Access This article is distributed under the terms of the Creative Commons Attribution Noncommercial License which permits any noncommercial use, distribution, and reproduction in any medium, provided the original author(s) and source are credited.

\section{References}

Arens SM, Geelen LHWT (2006) Dune landscape rejuvenation by intended destbilization in the Amsterdam water supply dunes. J Coast Res 22:1094-1107

Boorman LA (1993) The grazing of British sand dunes vegetation. In: Gimmingham $\mathrm{CH}$, Ritchie W, Willetts $\mathrm{BB}$, Willis AJ (eds) Coastal sand dunes, vol 96. pp, Proceeding of the Royal Society of Edinburgh, pp 75-88

van Boxel JH, Jungerius PD, Kieffer N, Hampele N (1997) Ecological effects of reactivation of artificially stabilised blowouts in coastal dunes. J Coast Conserv 3:57-62

Cape JN, van der Eerden LJ, Sheppard LJ, Leith ID, Sutton MA (2009) Evidence for changing the critical level for ammonia. Environ Pollut 157:1033-1037

Dargie TCD (1995) Sand dune vegetation survey of Great Britain-a national inventory. Part 3: Wales. Joint Nature Conservation Committee, Peterborough, UK

Department for Environment, Food and Rural Affairs (Defra) (2006) Flood and Coastal Defence Appraisal Guidance FCDPAG3 Economic Appraisal Supplementary Note to Operating Authorities - Climate Change Impacts October 2006 (online)

Enviroment Agency Wales (EAW) (2006) Assessment of the hydrological impacts of Environment Agency drainage activities on eight wetland SSSIs in North Wales. Report prepared by Water Management Consultants, Shrewsbury
Groves EW (1958) Hippophae rhamnoides in the British Isles. Proceeding of the Botanical Society of the British Isles 3:1-21

Hodgkin SE (1984) Scrub encroachment and its effects on soil fertility on Newborough Warren, Anglesey, Wales. Biol Conserv 29:99-119

Jones MLM, Reynolds B, Stevens PA, Norris D, \& Emmett BA (2002a) Changing nutrient budget if sand dunes: Consequences for nature conservation interest and dunes management. 1. A Review. Centre for Ecology and Hydrology, Bangor. CCW Contract Science Report no. 566ba

Jones MLM, Hayes F, Brittain SA, Haria S, Williams PD, Ashenden TW, Norris DA, \& Reynolds B (2002b) Changing nutrient budget of sand dunes: Consequences for nature conservation interest and dunes management. 2. Field Survey. Centre for Ecology and Hydrology, Bangor. CCW Contract Science Report no. 566b.

Jones MLM, Wallace HL, Norris D, Haria SA, Jones RE, Rhind PM, Reynolds BR, Emmett BA (2004) Changes in vegetation and soil characteristics in coastal sand dunes along a gradient of atmospheric nitrogen deposition. Plant Biol 6:598-605

Jones MLM, Pilkington MG, Healey M, Norris DA, Brittain SA, Tang SY Jones M, Reynolds B (2005) Determining a nitrogen budget for Merthyr Mawr sand dune system. Centre for Ecology and Hydrology. CCW Review of Consents Report Number: 14

May VJ, Hanson JD (2003) Coastal geomorphology of Great Britain. Geological conservation review series, Jount Nature Conservation Committee, Peterborough

Pearson MC, Rogers JA (1962) Hippophae rhamnoides L. J Ecol 50:501-513

Prendergast J, Quinn RM, Lawton JH, Eversham BC, Gibbons DW (1993) Rare species, the coincidence of diversity hotspots and conservation strategies. Nature, Lond 365:335-337

Pye K \& Saye S (2005) The geomorphological response of welsh sand dunes to sea level rise over the next 100 Years and the management implications for SAC and SSSI sites. CCW Contract Science Report No 670

Ranwell DS (1960) Newborough Warren, Anglesey III. Changes in the vegetation on parts of the dune system after the loss of rabbits by myxomatosis. J Ecol 48:385-395

Ranwell DS (ed) (1972) The management of sea buckthorn (Hippophae rhamnoides L.) on selected sites in Great Britain. Nature Conservancy Council

Ritchie W (2001) Coastal dunes: resultant dynamic position as a conservation managerial objective. In: Houston JA, Edmondson SE, Rooney PJ (eds) Coastal dune management. Shared experience of European conservation practice. Proceedings of the European Symposium Coastal Dunes of the Atlantic Biogeographical Region Southport, September 1998. Northwest England, Liverpool University Press

Rhind PM, Blackstock TH, Hardy HS, Jones RE, Sandison W (2001) The evolution of Newborough Warren dune system with particular reference to the past four decades. In: Houston JA, Edmondson SE, Rooney PJ (eds) Coastal dune management. Shared experience of European conservation practice. Proceedings of the European Symposium Coastal Dunes of the Atlantic Biogeographical Region Southport, September 1998. Northwest England, Liverpool University Press

Rhind PM, Jones PS (1999) The floristics and conservation status of sand-dune communities in Wales. J Coast Conserv 5:31-42

Saye SE (2003) Morphology and sedimentology of coastal sand dune systems in England and Wales. Unpublished $\mathrm{PhD}$ Thesis, University of London

Tolhurst S, \& Oates M (2001) The breeds profile handbook-a guide to the selection of livestock breeds for grazing wildlife sites. Published by English Nature for Grazing Animal Project (GAP)

Government UK (1994) Biodiversity: the UK Action Plan, CM 2428. HMSO, London 